\title{
sLAG-3 in non-small-cell lung cancer patients' serum
}

This article was published in the following Dove Press journal:

OncoTargets and Therapy

\begin{abstract}
Yayi $\mathrm{He}^{\mathrm{l}}$
Yan Wang'

Sha Zhao'

Chao Zhao'

Caicun Zhou'

Fred R Hirsch ${ }^{2}$

'Department of Medical Oncology, Shanghai Pulmonary Hospital, Tongji University Medical School Cancer Institute, Tongji University School of Medicine, Shanghai, China; ${ }^{2}$ Division of Medical Oncology, Department of Medicine, University of Colorado Anschutz Medical Campus, Aurora, CO, USA
\end{abstract}

Background: Anti-programmed cell death-1/programmed cell death ligand-1 monoclonal antibodies have been widely used in non-small-cell lung cancer (NSCLC), but not every patient can get benefits from them. Whether other molecular markers can predict the results of programmed cell death-1/programmed cell death ligand-1 inhibitors need to be explored. Lymphocyte-activation gene-3 (LAG-3) is another important immune checkpoint, which can inhibit tumor immunity. Soluble LAG-3 (sLAG-3) plays different functions from LAG-3. In this study, we detected the serum sLAG-3 level in NSCLC patients.

Methods: sLAG-3 was detected in 247 hospitalized patients by enzyme-linked immunosorbent assay. Every sample was repeated three times.

Results: Two-hundred forty-seven hospitalized patients were enrolled in this study. Of them, 71 had benign diseases and 176 were NSCLC patients. sLAG-3 in NSCLC serum was correlated with NSCLC stage. The sLAG-3 levels were significantly higher in stage I-II NSCLC than in stage III-IV $(p<0.001)$.

Conclusion: The advanced NSCLC had the lower SLAG-3 expression. This might be related to the poor cancer immune response. Increasing sLAG-3 level might be a promising treatment in advanced NSCLC patients.

Keywords: soluble lymphocyte-activation gene-3, non-small-cell lung cancer, immune therapy

\section{Introduction}

The incidence and mortality of lung cancer are higher. ${ }^{1}$ Lung cancer patients are always diagnosed at an advanced stage. ${ }^{2}$ Chemotherapy and targeted therapy are the standard treatments for advanced non-small-cell lung cancer (NSCLC). But not all patients can get benefit from these therapies. ${ }^{3-5}$ Therefore, it is very necessary to search a new treatment for NSCLC patients.

Immunotherapy has a good result in lung cancer patients. Many clinical trials, such as Checkmate-017, Checkmate-057, Keynote-010, Keynote-024, and OAK, showed that anti-programmed cell death-1 (PD-1)/programmed cell death ligand-1 (PD-L1) monoclonal antibodies could improve the objective response rate (ORR) and prolong the overall survival (OS) in NSCLC patients. The anti-PD-1/PD-L1 monoclonal antibodies have been approved for the standard NSCLC treatment by the US Food and Drug Administration. ${ }^{6-10}$

Similar to the targeted therapy, not all lung cancer patients can benefit from antiPD-1/PD-L1 monoclonal antibodies. Only 20\% of NSCLC patients can get benefit from the PD-1/PD-L1 inhibitors, ${ }^{7,8,10}$ and resistance is an inevitable problem. ${ }^{11}$ One study reported that when the patients faced the resistance of PD-1/PD-L1 inhibitor, T-cell immunoglobulin and mucin-domain containing-3 expression was significantly
Correspondence: Caicun Zhou Department of Medical Oncology, Shanghai Pulmonary Hospital, No 507 Zhengmin Road, Shanghai 200437, China Tel +8665 II 50063050

Email caicunzhoudr@I63.com
OncoTargets and Therapy 2018:I | 478|-4784 (c) (1) (2) $\odot 2018$ He et al. This work is published and licensed by Dove Medical Press Limited. The full terms of this license are avalable at https:/www.dovepress.com/terms.php

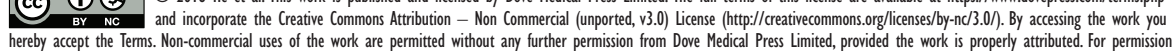
hereby accept the Terms. Non-commercial uses of the work are permitted without any further permission from Dove Medice
for commercial use of this work, please see paragraphs 4.2 and 5 of our Terms (https://www.dovepress.com/terms.php). 
increased, which suggested that the resistance of PD-1 inhibitor might be related to other immunological checkpoints compensatory high expression. ${ }^{12}$

Lymphocyte-activation gene-3 (LAG-3; CD 223) is another important immune checkpoint in lung cancer, ${ }^{13}$ which can bind a non-holomorphic region of major histocompatibility complex class II (MHC class II) with greater affinity than CD 4. ${ }^{14,15}$ LAG-3 can inhibit the cancer immune response and play a complicated role in the immune system. Soluble LAG-3 (sLAG-3) can induce dendritic cells to mature and attack tumor cells. ${ }^{16}$ In our previous study, we reported that the LAG-3 expression was correlated with PD-1/PD-L1 expression in NSCLC patients and was related to poor prognosis. In this study, we detected the serum sLAG-3 level in NSCLC patients.

\section{Methods}

\section{Patients}

From January 2016 to June 2017, 247 hospitalized patients were continuously enrolled in this study from Shanghai Pulmonary Hospital. Most of the serum samples were collected within 2 days prior to test. Samples were stored at $-80^{\circ} \mathrm{C}$ without repeated freeze and thaw. The feature of samples was blinded to the test before and after detecting sLAG-3. Blood samples were obtained before diagnosis and receiving any anticancer treatment. All participates signed the informed consent form. Pulmonary benign and NSCLC patients were diagnosed by histology. Lung cancer stages were categorized by seventh edition of International Association for the Study of Lung Cancer (IASLC) TNM staging system. The protocol was approved by the Shanghai Pulmonary Hospital, Tongji University.

\section{ELISA for sLAG-3}

sLAG-3 was detected by enzyme-linked immunosorbent assay (ELISA) kit (Uscn, Wuhan, China). Every sample was repeated three times.

\section{Statistical analysis}

We performed statistical analysis by SPSS 17.0. Chi-square tests were used to analyze the clinical data between benign diseases and NSCLC. The measurement material used the rank sum test. All statistics were two-sided, and statistical significance was defined as $p<0.05$.

\section{Results}

\section{Patient characteristics}

Two-hundred forty-seven hospitalized patients were continuously enrolled in this study from Shanghai Pulmonary Hospital. Of them, 71 had benign diseases and 176 were
Table I Clinical data of all cases

\begin{tabular}{llll}
\hline Characteristic & $\begin{array}{l}\text { Benign pulmonary } \\
\text { diseases }\end{array}$ & NSCLC & p-value \\
\hline $\begin{array}{l}\text { Sex, n (\%) } \\
\quad \text { Female }\end{array}$ & $18(25.4)$ & $4 I(23.3)$ & 0.743 \\
$\quad \begin{array}{l}\text { Male } \\
\text { Age (years), n (\%) }\end{array}$ & $53(74.6)$ & $135(76.7)$ & \\
$\quad \leq 70$ & $63(88.7)$ & $157(89.2)$ & 1.000 \\
$>70$ & $8(11.3)$ & $19(10.8)$ & \\
Smoker, n (\%) & & & \\
$\quad$ Smoker & $39(55.9)$ & $99(56.3)$ & 0.888 \\
$\quad$ Non-smoker & $32(45.1)$ & $77(43.8)$ & \\
Stage, n (\%) & & $103(58.5)$ & \\
I-II & - & $73(41.5)$ & \\
III-IV & - &
\end{tabular}

Abbreviation: NSCLC, non-small-cell lung cancer.

NSCLC patients. Table 1 shows the clinical data of all cases included in this study. In benign pulmonary diseases group, 53 (74.6\%) were males and 18 (25.4\%) were females. Eight $(11.3 \%)$ patients were $>70$ years old. Thirty-nine $(55.9 \%)$ patients had a smoking history. In the NSCLC group, there were $41(23.3 \%)$ females. Nineteen $(10.8 \%)$ were $>70$ years old. Ninety-nine $(56.3 \%)$ patients had a smoking history.

\section{sLAG-3 in different patients}

We did a subanalysis in patients with benign pulmonary diseases; the sLAG-3 levels were non-significant between sex, age, and smoking status. In NSCLC patients, the sLAG-3 levels were non-significant between sex, age, smoking status, and pathology. The sLAG-3 levels were significantly higher in stage I-II NSCLC than in stage III-IV ( $p<0.001$; Table 2$)$.

\section{Discussion}

To our knowledge, this is the first study to analyze serum sLAG-3 in NSCLC patients. In our previous study, we detected LAG-3 expression in NSCLC by immunohistochemistry. We reported that LAG-3 expression was correlated with PD-1/PD-L1 expression and was related to poor prognosis in NSCLC patients. ${ }^{17}$ In this study, we found that the serum sLAG-3 levels were significantly higher in earlystage NSCLC.

Immunotherapy has been widely recognized in the treatment of lung cancer. Anti-PD-1/PD-L1 monoclonal antibodies have been widely used in NSCLC. ${ }^{6-10}$ Although anti-PD-1/PD-L1 monoclonal antibodies have a good result in NSCLC patients, not all patients can get benefits from them. Some biomarkers can partly predict the efficacy of anti PD-1/PD-L1 monoclonal antibodies, such as PD-1, PD-L1 expression, and tumor mutation burden. ${ }^{6-10}$ Whether other molecular markers can predict the results of PD-1/PD-L1 
Table 2 sLAG-3 in different groups

\begin{tabular}{|c|c|c|c|c|c|c|}
\hline & $\begin{array}{l}\text { Benign pulmonary } \\
\text { diseases }\end{array}$ & $p$-value & NSCLC & $p$-value & Total & p-value \\
\hline \multicolumn{7}{|l|}{ Sex, mean rank } \\
\hline Female & 37.67 & 0.692 & 94.44 & 0.394 & 131.49 & 0.356 \\
\hline Male & 35.43 & & 86.70 & & 121.65 & \\
\hline \multicolumn{7}{|l|}{ Age (years), mean rank } \\
\hline$\leq 70$ & 35.94 & 0.942 & 88.63 & 0.924 & 124.10 & 0.948 \\
\hline$>70$ & 36.50 & & 87.45 & & 123.15 & \\
\hline \multicolumn{7}{|l|}{ Smoker, mean rank } \\
\hline Smoker & 34.11 & 0.484 & 87.25 & 0.774 & 120.33 & 0.473 \\
\hline Non-smoker & 37.55 & & 89.47 & & 126.90 & \\
\hline \multicolumn{7}{|l|}{ Stage, mean rank } \\
\hline I-II & - & - & 111.77 & $<0.001$ & - & - \\
\hline III-IV & - & & 55.66 & & - & \\
\hline \multicolumn{7}{|l|}{ Pathology, mean rank } \\
\hline Benign diseases & - & - & - & - & 132.02 & 0.262 \\
\hline NSCLC & - & & - & & 120.76 & \\
\hline \multicolumn{7}{|l|}{ Subpathology, mean rank } \\
\hline Adenocarcinoma & - & - & 94.79 & 0.158 & - & - \\
\hline Non-adenocarcinoma & - & & 83.83 & & - & \\
\hline
\end{tabular}

Abbreviations: NSCLC, non-small-cell lung cancer; sLAG-3, soluble LAG-3.

inhibitor needs to be explored. LAG-3 is another important immune checkpoint. ${ }^{13,17}$ LAG-3 can inhibit cancer immunity by negatively regulating $\mathrm{T}$ cell proliferation, activation, and homeostasis in cancer patients. In gastric cancer, LAG-3 and PD-1 expression on $\mathrm{T}$ cells impaired the postsurgery cell-mediated immunity. ${ }^{18}$ LAG-3 was highly expressed in hepatocellular carcinoma. ${ }^{19}$ Our group reported that LAG-3 was correlated with PD-1/PD-L1 expression, and higher expression of LAG-3 predicted poor prognosis in NSCLC. ${ }^{17}$ sLAG-3 plays different functions from LAG-3. sLAG-3 can induce dendritic cells attacking cancer cells. ${ }^{20,21}$ sLAG-3 can be detected in patient serum by ELISA. ${ }^{22}$ In this study, we found that SLAG-3 in NSCLC serum was correlated with the stages of NSCLC. The advanced lung cancer patients had the lower sLAG-3 expression. This might be related to the advanced disease patients having poor cancer immune response. Thus, increasing sLAG-3 level in advanced lung cancer might be a promising treatment in NSCLC patients.

There are some limitations in this study. First, we lacked the data of ORR and OS. Second, tumor tissue LAG-3, PD-1, and PD-L1 expressions should be analyzed in these patients. Furthermore, we will prospectively compare serum sLAG-3 level with tumor LAG-3, PD-1, and PD-L1 expressions and analyze the correlation of sLAG-3 with survival data in a large-scale study.

\section{Conclusion}

We detected sLAG-3 in NSCLC patients' serum and found that sLAG-3 was significantly lowly expressed in advanced-stage NSCLC. LAG-3 is an important immune checkpoint and may have synergistic function with PD-1/ PD-L1. sLAG-3 can improve the immune response of cancer. Whether sLAG-3 could become a new treatment and serve as a liquid biopsy biomarker for lung cancer immunotherapy need to be further explored.

\section{Acknowledgments}

This study was supported in part by a grant from Shanghai Pujiang Program (17PJD036), major disease clinical skills enhancement program of 3-year action plan for promoting clinical skills and clinical innovation in municipal hospitals, Shanghai Shen Kang Hospital Development Center "Clinical Research Plan" of SHDC (16CR1001A), and the fundamental research funds for the central universities.

\section{Disclosure}

The authors report no conflicts of interest in this work.

\section{References}

1. Chen W, Zheng R, Zhang S, Zou X, Zhao P, He J. Lung cancer incidence and mortality in China, 2009. Thorac Cancer. 2013;4:102-108.

2. Chen $\mathrm{W}$, Zheng R, Baade PD, et al. Cancer statistics in China, 2015. CA Cancer J Clin. 2016;66:115-132.

3. Keedy VL, Temin S, Somerfield MR, et al. American Society of Clinical Oncology provisional clinical opinion: epidermal growth factor receptor (EGFR) mutation testing for patients with advanced non-small-cell lung cancer considering first-line EGFR tyrosine kinase inhibitor therapy. J Clin Oncol. 2011;29:2121-2127.

4. Pennell NA. Integration of EGFR inhibitors and conventional chemotherapy in the treatment of non-small-cell lung cancer. Clin Lung Cancer. 2011;12:350-359. 
5. Zhou C, Wu YL, Chen G, et al. Erlotinib versus chemotherapy as first-line treatment for patients with advanced EGFR mutation-positive non-small-cell lung cancer (OPTIMAL, CTONG-0802): a multicentre, open-label, randomised, phase 3 study. Lancet Oncol. 2011;12: 735-742.

6. Reck M, Rodriguez-Abreu D, Robinson AG, et al. Pembrolizumab versus chemotherapy for PD-L1-positive non-small-cell lung cancer. N Engl J Med. 2016;375(19):1823-1833.

7. Brahmer J, Reckamp KL, Baas P, et al. Nivolumab versus docetaxel in advanced squamous-cell non-small-cell lung cancer. $N$ Engl J Med. 2015;373:123-135.

8. Borghaei H, Paz-Ares L, Horn L, et al. Nivolumab versus docetaxel in advanced nonsquamous non-small-cell lung cancer. $N$ Engl J Med. 2015;373:1627-1639.

9. Rittmeyer A, Barlesi F, Waterkamp D, et al; Group OAKS. Atezolizumab versus docetaxel in patients with previously treated non-smallcell lung cancer (OAK): a phase 3, open-label, multicentre randomised controlled trial. Lancet. 2017;389:255-265.

10. Herbst RS, Baas P, Kim DW, et al. Pembrolizumab versus docetaxel for previously treated, PD-L1-positive, advanced non-small-cell lung cancer (KEYNOTE-010): a randomised controlled trial. Lancet. 2016;387:1540-1550.

11. Sharma P, Hu-Lieskovan S, Wargo JA, Ribas A. Primary, adaptive, and acquired resistance to cancer immunotherapy. Cell. 2017;168:707-723.

12. Koyama S, Akbay EA, Li YY, et al. Adaptive resistance to therapeutic PD-1 blockade is associated with upregulation of alternative immune checkpoints. Nat Commun. 2016;7:10501.

13. He Y, Rivard CJ, Rozeboom L, et al. LAG-3, an important immune checkpoint in cancer. Cancer Sci. 2016;107(9):1193-1197.
14. Gagliani N, Magnani CF, Huber S, et al. Coexpression of CD49b and LAG-3 identifies human and mouse T regulatory type 1 cells. Nat Med. 2013;19:739-746.

15. Butler NS, Moebius J, Pewe LL, et al. Therapeutic blockade of PD-L1 and LAG-3 rapidly clears established blood-stage Plasmodium infection. Nat Immunol. 2012;13:188-195.

16. Demeure CE, Wolfers J, Martin-Garcia N, Gaulard P, Triebel F. T Lymphocytes infiltrating various tumour types express the $\mathrm{MHC}$ class II ligand lymphocyte activation gene-3 (LAG-3): role of LAG-3/ MHC class II interactions in cell-cell contacts. Eur J Cancer. 2001;37: 1709-1718.

17. He Y, Yu H, Rozeboom L, et al. LAG-3 protein expression in non-small cell lung cancer and its relationship with PD-1/PD-L1 and tumorinfiltrating lymphocytes. J Thorac Oncol. 2017;12:814-823.

18. Takaya S, Saito H, Ikeguchi M. Upregulation of immune checkpoint molecules, PD-1 and LAG-3, on CD4+ and CD8+ T cells after gastric cancer surgery. Yonago Acta Med. 2015;58:39-44.

19. Li FJ, Zhang Y, Jin GX, Yao L, Wu DQ. Expression of LAG-3 is coincident with the impaired effector function of $\mathrm{HBV}$-specific CD8(+) T cell in HCC patients. Immunol Lett. 2013;150:116-122.

20. Buisson S, Triebel F. MHC class II engagement by its ligand LAG-3 (CD223) leads to a distinct pattern of chemokine and chemokine receptor expression by human dendritic cells. Vaccine. 2003;21: $862-868$.

21. Andreae S, Buisson S, Triebel F. MHC class II signal transduction in human dendritic cells induced by a natural ligand, the LAG-3 protein (CD223). Blood. 2003;102:2130-2137.

22. Triebel F. LAG-3: a regulator of T-cell and DC responses and its use in therapeutic vaccination. Trends Immunol. 2003;24:619-622.
OncoTargets and Therapy

\section{Publish your work in this journal}

OncoTargets and Therapy is an international, peer-reviewed, open access journal focusing on the pathological basis of all cancers, potential targets for therapy and treatment protocols employed to improve the management of cancer patients. The journal also focuses on the impact of management programs and new therapeutic agents and protocols on

\section{Dovepress}

patient perspectives such as quality of life, adherence and satisfaction The manuscript management system is completely online and includes a very quick and fair peer-review system, which is all easy to use. Visit http://www.dovepress.com/testimonials.php to read real quotes from published authors. 